\title{
Efficiency of Public Procurement in Magelang City Government: AComparative Analysis
}

\author{
Madu Sadono $^{\mathrm{a}}$, Andy Fefta Wijaya ${ }^{\mathrm{b}}$, Alfi Haris Wanto $^{\mathrm{b}}$, Koji Fujimoto $^{\mathrm{c}} *$ \\ ${ }^{a}$ Regional Secretariat of Magelang City, Central Java, Indonesia \\ ${ }^{b}$ Brawijaya University, Malang, East Java, Indonesia \\ ${ }^{c}$ Takushoku University, Tokyo, Japan
}

\section{IN FORMASI ARTIKEL}

\section{Article history:}

Dikirim tanggal: 03 Oktober 2017

Revisi pertama tanggal: 24 Oktober 2017

Diterima tanggal: 15 November 2017

Tersedia online tanggal: 26 November 2017

Keywords: e-procurement, costefficiency, time-efficiency

\section{ABSTRACT}

This study aims to find out the public procurement process before and after the implementation of e-procurement in Magelang City Government and to assess whether the implementation of e- procurement has been or not improved in Magelang City Government. This study investigates cost efficiency, time efficiency and other aspect of efficiency in comparison with conventional procurement. This comparative study is useful to explain the procurement process before and after the implementation of e-procurement. The implementation of public procurement using e- procurement is more efficient compared with conventional procurement. There are problems that hinder the process of public procurement. The problem in the implementation of procurement in Magelang City is human resources. These problems prevented improvements in procurement in Magelang City.

2016 FIA UB. All rights reserved.

\section{Introduction}

In 1999, the government through BAPPENAS took the initiative to review the implementation of public procurement in Indonesia. BAPPENAS in cooperation with the World Bank conducted a review of the implementation of public procurement at the end of the new order era. The results of this study are the prices of goods and services above the market price. The government always buys goods above the market price with a margin between $10 \%$ and $50 \%$.

These results encourage the government to improve the public procurement system in Indonesia. Making the regulation that specifically regulates the implementation of the national public procurement is an effort to improve the quality of public procurement. Since 2000 , regulations on public procurement have been made and amended several times. The government does innovation in public procurement by making electronic procurement system (e-procurement). The eprocurement system began to be implemented in 2008 . Five local governments are designated as pilot projects to implement e-procurement. E-procurement was officially launched in 2010 with the issuance of Presidential Regulation No. 54/2010. By these regulations, Magelang City Government began to implement e-procurement by establishing the Electronic Procurement Services (LPSE) and Procurement Services Unit (ULP) in 2011.

National Procurement Agency (LKPP) states that eprocurement is more efficient compared with conventional procurement. Furthermore, this paper will investigate cost efficiency, time efficiency and other aspects of efficiency in comparison with conventional procurement. A comparative study is necessary because the new system of e-procurement is believed to be more valuable in terms of cost efficiency, time efficiency and other aspects of efficiency.

\section{Theory}

\subsection{Good Governance}

Governance has risen to prominence as a way of describing and explaining changes in the world (Bevir, 2011). The shift to greater use of markets, quasimarkets, and networks, especially in the delivery of public services from hierarchical bureaucracy are typical of this reform. Beginning in the 1980s, the way people perceive government and its administration had changed regarded to several trends, including globalization, 
devolution, and redefinition (Henry, 2004). According to (World Bank, 2014), good governance is a concept in the implementation of development management of reliable and responsible in line with the democratic and efficient markets, avoidance of wrong allocations and investments are rare and the prevention of corruption both political and administrative, running a budget discipline and the creation of a legal framework for the growth of entrepreneurial activity.

\subsection{E-procurement}

According to (Arrowsmith \& Trybus, 2002), public procurement is the purchasing by a government of the goods and services it requires to function and maximize public welfare. In doing so, a government will often adopt regulations and procedures to ensure that it obtains these goods, services or works (construction projects) in a transparent, competitive manner and at best price or the most economically advantageous price.

Procurement of goods and services have developed into electronic-based procurement. E-procurement is a technology designed to facilitate the procurement of goods and services over the internet. All procurement activities are prepared electronically, and the function of procurement is supported by electronic communications. Furthermore, according to the World Bank (2004), Electronic Government Procurement is the use of information and communication technologies by the government in implementing procurement to obtain goods and services required by the public sector.

Consistent with the above definition, Ippolito (2003) described e-procurement as a set of technologies, procedures and organizational measures which allow the purchase of goods and services online, through the opportunities offered by the internet and e-commerce. From the various definitions of e-procurement, it can be presumed that e-procurement is an information system that includes a procurement process to make it easier to get goods and services needed by the community in an effective and efficient manner. In other words, it changes the conventional procurement process into electronic procurement by utilizing information and communication technology.

\subsection{E-Procurement Objectives}

The Asian Development Bank in 2013 stated the objectives of e-procurement as follows:

(1) Transparency. Transparency is a principle that guarantees access, or the freedom of every person to obtain information about government administration, about the policy-making process and its implementation, as well as the results achieved. Transparency refers to the availability of information to the general public and clarity about the rules, laws, and government decisions.

(2) Efficiency. Reducing transaction costs, especially through electronic workflows and automated transaction processing, is a major source of cost savings for governments. The use of electronic workflows and better access can reduce the time required to complete the procurement process, leading to transactional efficiency for both suppliers and governments.

(3) Economy (value for money). E-procurement is reported to make significant savings in the cost of goods resulting in better quality at lower cost. These savings are due to increased competition through more bidding opportunities using the e-procurement platform. The use of e-procurement platforms is also an innovative way to upgrade purchasing power, to achieve economies of scale and to achieve the most value for money.

(4) Increased accessibility. An online announcement on an integrated website makes it easy for suppliers to get information and opportunities for bidding. The use of bidding documents electronically also makes it easier for suppliers to enter bids from anywhere.

(5) Economic development. E-procurement can be used as an instrument for promoting economic development through the growth of online technology. The adoption of information technology can significantly reduce transaction costs by using e-tendering, e-catalog, and epayment.

(6) Equitable and inclusive. The implementation of electronic public procurement gives micro, small, and medium-sized enterprises the opportunity to compete with large enterprises. A study revealed that the use of electronic government procurement has reduced the "bureaucratic costs of doing public sector business" (Dutra, et al., 2006).

From the above explanation, it can be concluded that the application of information technology in public procurement has many benefits for both government and suppliers. In achieving the objectives of e-procurement, it is necessary to analyze various issues as discuss above to improve efficiency.

\subsection{National Procurement Guidelines of Indonesia}

The issuance of Presidential Decree No.18/2000 in the reform period marked the start of new procurement rules. Although that decree moved the development paradigm to a more democratic political direction, many of the articles do not make procurement more open and modern.

Through Presidential Decree No. 80/2003 the government changed the public procurement process. The Head of BAPPENAS officially established National Public Procurement Agency (abbreviated as LKPP) under Presidential Decree No. 106/2007. LKPP is a non-departmental government agency which is directly responsible to the President. In carrying out its duties and functions, LKPP under the coordination of the State Minister of National Development Planning/Head of BAPPENAS.

LKPP efforts to improve the system of public procurement to elevate public welfare can be observed from the Presidential Decree on Public Procurement amendments as follows:

(1) Presidential Regulation No. 54/2010. This Presidential Decree stipulates that procurement begins when the budget plans are approved by a legislature. The most important thing in this decree is the start of the implementation of e-procurement nationally through LPSE.

(2) Presidential Regulation No. 35/2011. This presidential decree stipulates the procurement process of consulting services providers in the field of law to face a lawsuit from a particular party and the provisions of 
consulting services providers in the context of mitigation of natural disasters through direct appointment.

(3) Presidential Regulation No. 70/2012. This decree stipulates the technical guidelines of procurement issued by the Head of LKPP. It determines that if there are changes in the terms regarding the technical implementation of procurement, the revisions do not need to be changed by Presidential Decree, which takes longer, but directly through regulations by the Head of LKPP.

(4) Presidential Regulation No. 172/2014. This decree stipulates a procurement process to accelerate the supply of seeds and fertilizers to farmers through direct appointment, and thereby to achieve food selfsufficiency.

(5) Presidential Regulation No. 4/2015. In this Presidential Decree, the mandatory use of electronic procurement of goods and services is stipulated, simplifying provider requirements in participating eprocurement.

From these Presidential Regulation detailed above, the roles and responsibilities of procurement organizations can be explained as follows.

(1) National Public Procurement Agency (LKPP) is a non-departmental government agency, the main duties of which are preparation and formulation of policies and strategies, as well as the determination of, the standard procedures for public procurement; it is also responsible for developing information systems and monitoring e-procurement implementation.

(2) Procurement Service Unit (ULP) is a government organization that has the function of carrying out eprocurement.

(3) Electronic Procurement Services (LPSE) is a unit formed across ministries, agencies, institutions, and local governments to manage e-procurement services and facilitate the Procurement Service Unit (ULP) in carrying out e-procurement.

\section{Research Method}

The analysis compares ten specific case studies of projects listed in Table 3.1. Out of the ten projects, eight are e-procurement projects, and two are conventional procurement projects. All the projects were selected on one condition that their costs exceeded 200 million rupiahs. The following ten projects were thus completed in the budget years from 2008 to 2016.

Table 3.1. Conventional Procurement and Eprocurement Project Information

\begin{tabular}{|c|c|c|c|}
\hline $\begin{array}{c}\text { Project } \\
\text { Code }\end{array}$ & Project Name & $\begin{array}{l}\text { Budget } \\
\text { (rupiah) }\end{array}$ & $\begin{array}{c}\text { Method of } \\
\text { Procurement }\end{array}$ \\
\hline Project A & $\begin{array}{l}\text { Agricultural Extension } \\
\text { Centers Building } \\
\text { Renovation of } \\
\text { Magelang City } \\
\text { Structuring the }\end{array}$ & $270,000,000$ & e-procurement \\
\hline Project B & $\begin{array}{l}\text { Cultural District } \\
\text { Mantyasih Phase II }\end{array}$ & $1,049,694,000$ & e-procurement \\
\hline Project $\mathrm{C}$ & $\begin{array}{l}\text { The construction / } \\
\text { renovation of } \\
\text { Slaughterhouse }\end{array}$ & $215,290,000$ & e-procurement \\
\hline Project D & $\begin{array}{l}\text { Street Vendors (PKL) } \\
\text { shelter construction for }\end{array}$ & $990,000,000$ & e-procurement \\
\hline
\end{tabular}

\begin{tabular}{|c|c|c|c|}
\hline & $\begin{array}{l}\text { the culinary economic } \\
\text { center of the Tidar } \\
\text { Valley }\end{array}$ & & \\
\hline Project E & $\begin{array}{l}\text { Development of } \\
\text { inpatient building in } \\
\text { the Tidar Magelang } \\
\text { City Hospital }\end{array}$ & $13,965,200,000$ & e-procurement \\
\hline Project F & $\begin{array}{l}\text { Bridge construction of } \\
\text { Margoharjo Magelang } \\
\text { City }\end{array}$ & $277,433,000$ & e-procurement \\
\hline Project G & $\begin{array}{l}\text { Improvement and } \\
\text { maintenance of roads } \\
\text { (package 1) of } \\
\text { Magelang City }\end{array}$ & $2,554,735,000$ & e-procurement \\
\hline Project $\mathrm{H}$ & $\begin{array}{l}\text { Rejowinangun Market } \\
\text { Building Construction }\end{array}$ & $63,341,265,000$ & e-procurement \\
\hline Project I & $\begin{array}{l}\text { Connecting Road } \\
\text { Construction North } \\
\text { Kramat Village - } \\
\text { South Kramat Village, } \\
\text { North Magelang } \\
\text { District }\end{array}$ & $1,801,119,000$ & $\begin{array}{l}\text { Conventional } \\
\text { procurement }\end{array}$ \\
\hline Project $\mathrm{J}$ & $\begin{array}{l}\text { Road construction } \\
\text { Jurangombo - Nepak }\end{array}$ & $2,200,000,000$ & $\begin{array}{l}\text { Conventional } \\
\text { procurement }\end{array}$ \\
\hline
\end{tabular}

Data used in the comparative analysis is a construction project. Construction projects are taken as samples because construction projects require resources (workers, costs, and materials), and their implementation adopts a long time. Moreover, the results of construction work can be utilized directly by the community in the form of infrastructure improvement in Magelang City.

Since 2011, the ULP of Magelang has implemented 174 construction projects. This amount is more than the procurement of goods and consulting services with 62 projects and 27 projects respectively. In this paper, a random sample of eight projects was drawn between 2011 and 2016. The sample data for conventional procurement used in this paper is limited. This limitation is caused by the conventional procurement implemented by each office independently and the regulation of document archive restrictions.

\section{Result and Discussion}

\subsection{Cost Efficiency Comparison}

Regulations on cost efficiency are mentioned in both presidential regulations. In both regulations mentioned that the bid price should be $80-100 \%$ of the price estimate. The winner of the tender is determined through the process of bid evaluation, and the bidder with the lowest evaluated price will be the winner. This rule is applied in both conventional public procurement and eprocurement. The cost efficiency is derived from the difference between the budget and the bidding prices. The cost efficiency of ten case studies of projects is listed in Table 4.1.

Table 4.1. Difference between Project Budget and Contract Price Price

\begin{tabular}{ccrrr}
\multicolumn{5}{c}{ Contract Price Price } \\
\cline { 1 - 2 } No. & $\begin{array}{c}\text { Project } \\
\text { Code }\end{array}$ & \multicolumn{1}{c}{ Budget } & Contract Price & Percentage \\
\cline { 2 - 2 } 1 & Project A & $270,000,000$ & $233,570,000$ & $13.49 \%$ \\
2 & Project B & $1,049,694,000$ & $1,017,785,000$ & $3.04 \%$ \\
3 & Project C & $215,290,000$ & $208,500,000$ & $3.15 \%$ \\
4 & Project D & $990,000,000$ & $963,500,000$ & $2.68 \%$ \\
5 & Project E & $13,965,200,000$ & $10,922,731,000$ & $21.79 \%$ \\
6 & Project F & $277,433,000$ & $249,970,000$ & $9.90 \%$
\end{tabular}




\begin{tabular}{ccrrr}
7 & Project G & $2,554,735,000$ & $2,487,534,000$ & $2.63 \%$ \\
8 & Project H & $63,341,265,000$ & $56,160,460,000$ & $11.34 \%$ \\
\hline & Total & $\mathbf{8 2 , 6 6 3 , 6 1 7 , 0 0 0}$ & $\mathbf{7 2 , 2 4 4 , 0 5 0 , 0 0 0}$ & $\mathbf{1 2 . 6 0 \%}$ \\
\hline 9 & Project I & $1,801,119,000$ & $1,474,292,000$ & $18.15 \%$ \\
10 & Project J & $2,200,000,000$ & $2,093,688,000$ & $4.83 \%$ \\
\hline & Total & $\mathbf{4 , 0 0 1 , 1 1 9 , 0 0 0}$ & $\mathbf{3 , 5 6 7 , 9 8 0 , 0 0 0}$ & $\mathbf{1 0 . 8 3 \%}$ \\
\hline
\end{tabular}

Source: LPSE (2017) and Annual Budget Report (20082010)

In the e-procurement, cost efficiency is recorded on an average of $12.60 \%$. This result is in line with costefficiency data from LKPP. In the period 2008-2017, eprocurement in Magelang shows the cost efficiency of $8.68 \%$. In the conventional procurement, the cost efficiency is recorded on an average $10.83 \%$.

From the above data, it can be concluded that eprocurement is more cost efficient than conventional procurement. Details about the cost efficiency in construction projects in e-procurement stipulated in the Regulation of the Minister of Public Works No. $14 / \mathrm{PRT} / \mathrm{M} / 2013$ as a guidelines in conducting construction projects in Indonesia. This regulation requires setting a price estimate based on market price, and a minimum bidding price limited to $80 \%$ of the price estimate. The construction project whose price is below $80 \%$ of the price estimate is acceptable, but it is necessary to evaluate the reasonableness of the price.

\subsection{Time Efficiency Comparison}

\section{A. Time Allocation}

The recommended time allocation for conventional procurement is stipulated in Presidential Decree No. 80/2003. The regulation stated that the allocation of time needed to perform conventional procurement is 23 (twenty-three) days. Allocation of time needed to implement e-procurement is 22 (twenty-two) days. This provision is regulated in Presidential Regulation No. $54 / 2010$. However, in practice, the time allocation of procurement in Magelang City exceed the recommended time in both the presidential decrees. Table 4.2. shown detail of the time allocated in e-procurement and conventional procurement.

Table 4.2. Number of Participants and Time Allocation

\begin{tabular}{|c|c|c|c|c|}
\hline No & $\begin{array}{c}\text { Project } \\
\text { Code }\end{array}$ & Budget & $\begin{array}{c}\text { Registered } \\
\text { Company }\end{array}$ & $\begin{array}{c}\text { Time } \\
\text { Allocation } \\
\end{array}$ \\
\hline 1 & Project A & $270,000,000$ & 24 & 25 \\
\hline 2 & Project B & $1,049,694,000$ & 28 & 32 \\
\hline 3 & Project C & $215,290,000$ & 56 & 36 \\
\hline 4 & Project D & $990,000,000$ & 35 & 23 \\
\hline 5 & Project E & $13,965,200,000$ & 31 & 44 \\
\hline 6 & Project F & $277,433,000$ & 22 & 38 \\
\hline 7 & Project G & $2,554,735,000$ & 20 & 41 \\
\hline 8 & Project $\mathrm{H}$ & $63,341,265,000$ & 43 & 82 \\
\hline \multicolumn{3}{|c|}{ Total } & 31 & 34 \\
\hline 9 & Project I & $1,801,119,000$ & 14 & 53 \\
\hline 10 & Project $\mathbf{J}$ & $2,200,000,000$ & 16 & 48 \\
\hline
\end{tabular}

Source: LPSE (2017) and Annual Budget Report (20082010)

In the conventional procurement, the average time allocation is 51 days. In the e-procurement, the average time allocation is 34 days. This number is obtained from an average of seven e-procurement projects without Project $\mathrm{H}$. Project $\mathrm{H}$ is the first e-procurement project implemented by ULP. Working group members were inexperienced in implementing e-procurement with a large amount of the budget. This project took 82 days to complete the procurement processes.

The number of companies which took part in the conventional procurement tenders averaged 15 companies. This is because conventional procurement announcements were made only in Magelang City. In contrast, the number of participants in each eprocurement tender is more than 20 companies. Procurement announcements through a website allows more companies from outside the city to participate in the tender.

It can be concluded that the actual procurement time for both conventional procurement and e-procurement exceeds the time specified in the presidential decree. Announcements through the website can expand procurement information and can be accessed from outside the city.

\section{B. Stage by Stage Time Allocation Comparison}

The actual time allocation for both methods exceeds the time specified in the presidential decree. To determine the reason for this, the time allocation for each of the procurement stages will be elaborated. Detailed stages and time allocation for conventional procurement and eprocurement is shown in Table 4.3.

Table 4.3. Stages Comparison of Public Procurement

\begin{tabular}{|c|c|c|c|}
\hline \multicolumn{2}{|c|}{$\begin{array}{c}\text { Conventional Procurement } \\
\text { (Presidential Decree No.80/2003) }\end{array}$} & \multicolumn{2}{|c|}{$\begin{array}{c}\text { E-procurement } \\
\text { (Presidential Decree No.54/2010) } \\
\end{array}$} \\
\hline & Stages & & Stages \\
\hline Stage 1 & Announcement & Stage 1 & Announcement \\
\hline Stage 2 & $\begin{array}{l}\text { Pickup the } \\
\text { Procurement Document }\end{array}$ & Stage 2 & $\begin{array}{l}\text { Download the } \\
\text { Procurement Document }\end{array}$ \\
\hline Stage 3 & $\begin{array}{l}\text { Explanation of } \\
\text { Procurement / } \\
\text { Aanwijzing }\end{array}$ & Stage 3 & $\begin{array}{l}\text { Explanation of } \\
\text { Procurement / } \\
\text { Aanwijzing }\end{array}$ \\
\hline Stage 4 & $\begin{array}{l}\text { Submission of bidding } \\
\text { documents }\end{array}$ & Stage 4 & $\begin{array}{l}\text { Upload of bidding } \\
\text { documents }\end{array}$ \\
\hline Stage 5 & $\begin{array}{l}\text { Opening of bidding } \\
\text { documents }\end{array}$ & Stage 5 & $\begin{array}{l}\text { Opening of bidding } \\
\text { documents }\end{array}$ \\
\hline Stage 6 & $\begin{array}{l}\text { Evaluation of bidding } \\
\text { document, including } \\
\text { evaluation of } \\
\text { qualifications }\end{array}$ & Stage 6 & Evaluation of bids \\
\hline Stage 7 & $\begin{array}{l}\text { Propose the Potential } \\
\text { Winner }\end{array}$ & Stage 7 & $\begin{array}{l}\text { Evaluation of bidding } \\
\text { document, including } \\
\text { evaluation of } \\
\text { qualifications }\end{array}$ \\
\hline Stage 8 & $\begin{array}{l}\text { Determination and } \\
\text { Announcement the } \\
\text { Winner }\end{array}$ & Stage 8 & $\begin{array}{l}\text { Propose the Potential } \\
\text { Winner }\end{array}$ \\
\hline Stage 9 & Objection period & Stage 9 & $\begin{array}{l}\text { Determination and } \\
\text { Announcement the } \\
\text { Winner }\end{array}$ \\
\hline $\begin{array}{c}\text { Stage } \\
10\end{array}$ & $\begin{array}{l}\text { Appointment Letter of } \\
\text { Provider }\end{array}$ & $\begin{array}{l}\text { Stage } \\
10\end{array}$ & $\begin{array}{l}\text { Objection Period of } \\
\text { Procurement Results }\end{array}$ \\
\hline $\begin{array}{l}\text { Stage } \\
11\end{array}$ & Signing of Contract & $\begin{array}{l}\text { Stage } \\
11 \\
\text { Stage } \\
12\end{array}$ & $\begin{array}{l}\text { Appointment Letter of } \\
\text { Provider } \\
\text { Signing of Contract }\end{array}$ \\
\hline
\end{tabular}

Source: Presidential Decree No. 80/2003 and Presidential Decree No. 54/2010

The above table is the number of days recommended in every stage of the procurement. In conventional 
procurement, there are eleven stages of procurement with a total allocation of time required 23 (twenty-three) days. In e-procurement, there are twelve stages with a total allocation of time which take shorter at 22 (twentytwo) days. The time recommendation in these both Presidential Regulations is useful to know which stage requires longer time allocation.
For e-procurement, procurement time recommendations stated in Presidential Decree No. 54/2010. A comparison of time allocation for each stage of eprocurement under Presidential Regulation No. 54/2010 is shown in Table 4.4 .

Table 4.4. Comparison of Time Allocation of E-Procurement Process under Presidential Regulation No.54/2010

\begin{tabular}{ccccccccccc}
\hline No & Stages & $\begin{array}{c}\text { Recommended } \\
\text { Time }\end{array}$ & $\begin{array}{c}\text { Project } \\
\text { A }\end{array}$ & $\begin{array}{c}\text { Project } \\
\text { B }\end{array}$ & $\begin{array}{c}\text { Project } \\
\text { C }\end{array}$ & $\begin{array}{c}\text { Project } \\
\text { D }\end{array}$ & $\begin{array}{c}\text { Project } \\
\text { E }\end{array}$ & $\begin{array}{c}\text { Project } \\
\text { F }\end{array}$ & $\begin{array}{c}\text { Project } \\
\text { G }\end{array}$ & $\begin{array}{c}\text { Project } \\
\text { H }\end{array}$ \\
\hline 1 & Stage 1 & 7 & 9 & 5 & 5 & 5 & 8 & 6 & 3 & 12 \\
2 & Stage 2 & 10 & 9 & 7 & 11 & 11 & 12 & 12 & 8 & 21 \\
3 & Stage 3 & 1 & 1 & 1 & 1 & 1 & 1 & 1 & 1 & 1 \\
4 & Stage 4 & 7 & 6 & 4 & 7 & 7 & 8 & 10 & 5 & 9 \\
5 & Stage 5 & 1 & 1 & 15 & 8 & 4 & 1 & 2 & 1 & 16 \\
6 & Stage 6 & 3 & 7 & 14 & 8 & 4 & 17 & 9 & 9 & 15 \\
7 & Stage 7 & 3 & 7 & 14 & 8 & 4 & 17 & 9 & 9 & 15 \\
8 & Stage 8 & 1 & 1 & 2 & 1 & 1 & 1 & 1 & 9 & 12 \\
9 & Stage 9 & 1 & 1 & 2 & 1 & 1 & 1 & 1 & 9 & 12 \\
10 & Stage 10 & 5 & 3 & 3 & 3 & 3 & 7 & 4 & 3 & 10 \\
11 & Stage 11 & 1 & 1 & 1 & 2 & 2 & 3 & 1 & 1 & 1 \\
12 & Stage 12 & 1 & 4 & 4 & 6 & 2 & 10 & 10 & 15 & 18 \\
\hline
\end{tabular}

Source: Author (2017)

From the table above it can be seen that some stages exceed the allocation of time recommended in Presidential Regulation No.54 / 2010. The stages are bid evaluation (stage 6), bidding document evaluation (stage 7 ), and signing of contract (stage 12). The cause of this problem is the inexperience of the working group handling the project. Also, procurement activities are undertaken by a few people, which hinders the process of procurement. One member of the working group tenders at one time. This makes the procurement process longer. In turn, delays in the completion of the tender may affect the other procurement schedules.

For conventional procurement, the procurement time recommendation is mentioned in Presidential Regulation No. 80/2003. The following table shows the comparison of time allocations for each stage with a time recommendation in Presidential Regulation No. 80/2003.

Table 4.5. Comparison of Time Allocation of Conventional Procurement Process with Presidential Regulation No.80/2003

\begin{tabular}{ccccc}
\hline No & Stages & $\begin{array}{c}\text { Recommeded } \\
\text { Time }\end{array}$ & Project I & Project J \\
\cline { 3 - 3 } 1 & Stage 1 & 7 & 10 & 15 \\
2 & Stage 2 & 13 & 14 & 14 \\
3 & Stage 3 & 1 & 1 & 1 \\
4 & Stage 4 & 7 & 8 & 8 \\
5 & Stage 5 & 1 & 2 & 2 \\
6 & Stage 6 & 1 & 8 & 12 \\
7 & Stage 7 & 1 & 2 & 2 \\
8 & Stage 8 & 1 & 1 & 1 \\
9 & Stage 9 & 5 & 5 & 5 \\
10 & Stage 10 & 1 & 1 & 1 \\
11 & Stage 11 & 1 & 1 & 1 \\
\hline
\end{tabular}

Source: Author (2017)
From the table above it can be seen that almost all the stages exceed the time recommended in Presidential Regulation No. 80/2003. The cause of the length of the procurement is that no agency focuses on procurement such as ULP and lacks experienced human resources in procurement. The procurement committee members are selected and acquired from several offices who have procurement certificates.

It can be concluded that the allocation time of eprocurement is more efficient than conventional procurement. But some problems hinder the implementation of the procurement one of them is the lack of human resources who have sufficient experience in implementing public procurement in Magelang.

\section{Other Aspect of Efficiency}

Before e-procurement is implemented, conventional procurement is carried out independently by each office. There is no specific organization that conducts procurement in Magelang City. After the issuance of Presidential Regulation No. 54/2010, the Magelang City Government established ULP to carry out electronic procurement. ULP of Magelang City is ad-hoc and consists of administrative staff and procurement officers. Members of ULP are taken from procurement certified civil servants in different office.

According to Mayoral Regulation of Magelang City Government No. 11/2015, ULP Magelang City Government is under the supervision of the Development Section of the Regional Secretariat of Magelang City Government. The organizational structure of ULP Magelang City Government can be seen in the following figure. 
Figure 4.1. Structural Organization of ULP of Magelang City Government

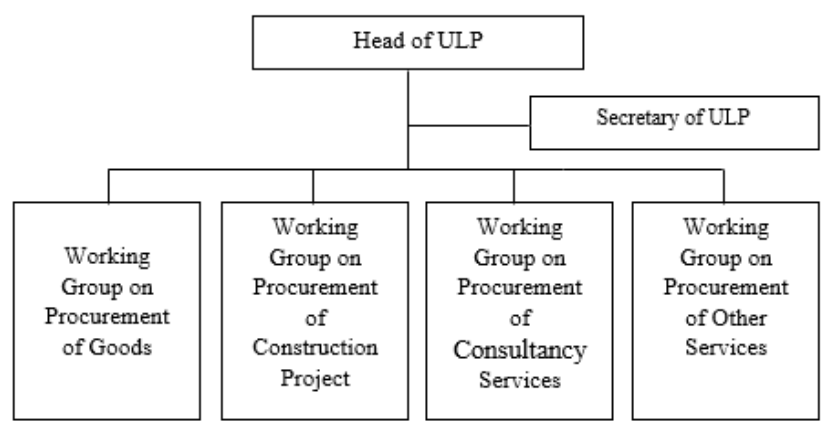

Source: Mayoral Regulation No. 11/2015

ULP responsibilities according to the Mayoral Regulation are to ensure the procurement of goods and services in Magelang City by the procurement regulation. To perform these tasks, Magelang City ULP is headed by a chairman, assisted by the working group. The Working Group has the responsibility to carry out procurement through e-procurement.

With the existence of ULP, the implementation of procurement in Magelang City became more efficient. This forms more positive perception among local government officials towards procurement efficiency. The more efficient procurement will have an impact on economic development in general in Magelang City. The local officials are aware of the importance of eprocurement, thus encouraging project manager to implement procurement of which project as construction projects efficiently. This impact can be seen from construction projects that are completed in time with good quality.

It can be concluded that e-procurement can change perceptions of government officials. Procurement efficiency is a major factor in development in Magelang City. The establishment of ULP in Magelang City supports the improvement of procurement efficiency. ULP becomes an organization that has full responsibility for conducting procurement in real time.

\section{Recommendations for Better Public Procurement in Magelang City Government}

Implementation of e-procurement in Magelang proved to be more efficient in terms of cost efficiency, time efficiency and other aspects of efficiency. In the implementation of procurement in the City of Magelang there are obstacles that hinder the implementation. They are organizational constraints in ULP and lack of experience and knowledge of procurement officials. The following recommendations are expected to improve policies and improve public procurement in Magelang City.

To solve organizational problems, the Magelang City Government needs to make ULP's permanent and independent status and make the status of the ULP members permanent (specialist procurement officers). Two of these recommendations are focused on the productivity of procurement officials in ULP. Today, the status of the ULP in Magelang is still ad-hoc working group drawn from several offices. This makes procurement officials difficult to engage in procurement jobs because they have to carry out work in their original offices.

For human resource constraints, the Magelang City Government needs to provide regular training on the procurement for the concerned civil servants and regenerate capable officials of the ULP in an orderly manner. Two of these recommendations are useful for improving human resources in ULP in Magelang, which otherwise would become an obstacle to the implementation of the procurement. Therefore, training is very helpful for increasing knowledge about procurement. The electronic procurement system is growing rapidly, so awareness raising and training programs on it need to be held. A better combination of ULP experienced members and inexperienced new members should be planned and practiced.

The Magelang City Government needs to prepare progress reports such as monthly reports and annual reports. The report could be used to monitor and evaluate the implementation of public procurement in Magelang City. Besides, it is necessary to learn the experience of other local governments who have been successfully implementing e-procurement. To further improve procurement services, the city government should learn from these experiences and re-invent them in Magelang City Government.

In general, the implementation of e-procurement in Magelang City is more efficient in the term of cost efficiency, time efficiency and other aspect of efficiency than public procurement before the implementation of eprocurement. The biggest problem in the public procurement services in Magelang City is human resources. The analysis of the recommedation above focuses on improving the three aspects of procurement implementation in Magelang City. They are the organizational aspect, human resources aspect, and documentation aspect. The recommendation are thus expected to address and improve public procurement services in Magelang City.

\section{Conclusion}

The objective of e-procurement in Indonesia is to make public procurement more efficient. Since 2008, the implementation of e-procurement is considered more benefited in aspects of efficiency. This paper investigates cost efficiency, time efficiency and other aspect of efficiency in comparison with conventional procurement.

Cost efficiency in procurement is estimated from the difference between the bidding price and the procurement budget. Public procurement before and after the implementation of e-procurement have equally benefited cost efficiency. In the conventional procurement, cost efficiency is recorded $10.83 \%$. In the e-procurement, cost efficiency is recorded $12.60 \%$.

By Presidential Regulation No. 80/2003, required time allocation for conventional procurement is 23 
(twenty-three) working days. For e-procurement, the required time allocation is 22 (twenty-two) days as stipulated in Presidential Regulation No. 54/2010.Time efficiency is used as one measure in determining efficiency. Time efficiency is seen from a comparison of time before and after the procurement of e-procurement. In the conventional procurement, the average time allocation is 51 days. In the e-procurement, the average time allocation is 40 days. In the implementation of public procurement in Magelang City it can be seen that the e-procurement process is more efficient than conventional procurement. However, the time allocation is longer than allowed under both presidential decrees. The lack of human resources in the ULP working group had negative impacts in the length of the procurement process.

Before e-procurement is implemented in Magelang City, conventional procurement is carried out independently by each office. This is due to the absence of a special organization that conducts procurement. Implementation of e-procurement shapes more possitive perception towards procurement efficiency. The more efficient the procurement will have an impact on economic development in Magelang City. This impact can be seen from construction projects that are completed in time with good quality.

The limitation of this paper is that construction projects whose values are more than 200 million rupiahs are used. Another is that the samples were small as two or three projects were taken up annually. For further studies, the limitation above as well as other procurement project should be included. It should also be kept in mind that considerations related other procurement objectives will be needed to deeper the analysis.

\section{References}

Arrowsmith, S., \& Trybus, M. (2002). Public procurement: The continuing revolution. Netherlands: Springer .

Asian Development Bank. (2013). e-Government Procurement Handbook. Philippines: Asian Development Bank.

Bevir, M. (2011). Governance. . London: Sage Publication.

Dutra, I., Findlay, C., McGregor, M., \& McEwan, T. (2006). E-procurement \& the SME: challenges for Scotland. Proceedings of IADIS International Conference e-Commerce, 281-286.

Henry, N. (2004). Public Administration and Public Affair. New Jersey: Pearson Prentice Hall.

Ippolito, S. (2003). Knowing E- procurement. Information Sistems Forensic Assosiation. Inc.

Presidential Decree on Guidelines on Procurement of Goods/Services in Government Agencies, 18 (2000).

Presidential Decree on Guidelines on Procurement of Government Goods/Services,
(2003).Presidential Regulation on Procurement of Government Goods/Services, 54 (2010).

Magelang Mayoral Regulation on Electronic Procurement Service of Magelang City, 31 (2011).

Magelang Mayoral Regulation on Procurement Service Unit of Magelang City, 71 (2012).

World Bank. (2004). Electronic government procurement $(e-G P)$ : readiness self assessment. Washington, DC: World Bank Group. 